\section{OPEN JOURNAL SYSTEMS}

ISSN:2237-2202
Available on line at Directory of Open Access Journals

Journal of Hyperspectral Remote Sensing v.7, n.6 (2017) 334-344

www.periodicos.ufpe.br/revistas/jhrs
Journal of Hyperspectral Remote Sensing

\title{
Quantile technique to precipitation, rainfall anomaly index and biophysical parameters by remote sensing in Serra Talhada, Pernambuco
}

\author{
Frederico A. C. Lins", Jhon L. B. da Silva**, Geber B. de A. Moura***, Pedro F. S. Ortiz ${ }^{* * * *}$, José D. A. Oliveira****, \\ Maria V. C. Alves**** \\ * Master's student in Agricultural Engineerin, Pós-Graduação em Engenharia Agrícola, Universidade Federal Rural de Pernambuco \\ - UFRPE. Av. D. Manoel de Medeiros, SN; Dois Irmãos, Recife, Pernambuco, Brazil. CEP: 52171-900. E-mail: \\ frederico_acl@hotmail.com (Corresponding author). \\ ** MSc in Agricultural Engineerin, Pós-Graduação em Engenharia Agrícola - UFRPE. E-mail: jhonlennoigt@ hotmail.com \\ ${ }^{* * *}$ Ph.D. in Oceanography, Associate professor at UFRPE. E-mail: geber@depa.ufrpe.br \\ **** MSc in Agricultural Engineerin, Pós-Graduação em Engenharia Agrícola - UFRPE. E-mail: francisko369@gmail.com \\ ***** MSc in Agricultural Engineerin, Pós-Graduação em Engenharia Agrícola - UFRPE. E-mail: josediorgenes@ gmail.com \\ ****** Graduating in Agronomy at UFRPE. E-mail: victtoria.ac@gmail.com
}

Received 13 June 2017; accepted 30 October 2017

\begin{abstract}
The occurrence of extreme events is a current reality that causes socioeconomic and environmental damages in the world. Increasingly, the occurrence of these events and their relation to anthropic actions are being investigated. Several methods have been used to identify and characterize extreme events to precipitation, mainly the quantile technique and the rainfall anomaly index (RAI). The objective of this paper was to identify years with extreme events to precipitation and to evaluate biophysical parameters to the surface by remote sensing through the use of orbital images. Parameters such as surface albedo, Normalized Difference Vegetation Index (NDVI) for years with extreme events were estimated using the ERDAS IMAGINE ${ }^{\circledR}$ 9.1 Software, from the implementation of the SEBAL algorithm. The study area is located in the municipality of Serra Talhada, Pernambuco. The thematic maps of the region were generated from the ArcGIS ${ }^{\circledR}$ 10.2.2 Software. For the Quantile of the years 1993, 1998, 2012, 2016 were classified as very dry, and for RAI the years 1993, 1998, 2012 were classified as extremely dry. The main differences between albedo and NDVI were observed through descriptive statistics. Quantile technique allowed the classification of annual precipitations, showing the interannual rainfall variability in the years 2011 and 2012, also confirming that the average for the normal years is characteristic of the semi-arid region. RAI allowed to identify the largest extreme events of precipitation in the years 1989 and 1998 . The surface albedo had little variation due to the spatial and temporal analysis of the images, as did the NDVI. However, both the rainfall anomaly index and the Quantile technique are relevant and effective tools for rainfall classification and the remote sensing techniques as a tool to investigate the use and occupation of the soil, proved to be of great importance, helping the management and conservation of the soil.
\end{abstract}

Keywords: extreme events, surface albedo, NDVI, meteorology.

\section{Introduction}

The occurrence of extreme events is a current reality that causes socioeconomic and environmental damages in the world. Increasingly, the occurrence of these events and their relation to anthropic actions are being investigated. $\mathrm{t}$ is known, however, that there are phenomena that cause these events and that have no relation with the actions of man, as is the case of El niño and La niña, which has great influence on the climate in the Brazilian northeast.
Serra Talhada-PE is situated in the Brazilian semiarid and is characterized by vegetation of caatinga (exclusively Brazilian biome) which according to many authors cite the vulnerability on the risk of desertification. The studies evaluating the impacts of climate change on the stability of the biomes prevailing in Brazil indicate that the Caatinga is among one of the most vulnerable vegetation with increasing temperatures on the planet, placing in alert mode the Northeast region of Brazil (Nobre, 2011). 
Northeast Brazil presents marked interannual variability, particularly precipitation and the availability of water resources, in extremely dry or other rainy years. Because of the irregularity of rainfall and low rainfall (less than $800 \mathrm{~mm}$ per year) much of the region has low disponivilidade water, mainly affecting the development of land and agricultural activities, among others (Marengo, 2011).

Several methods have been used in this semiarid region to identify and characterize extreme precipitation events, such as the Quantile technique, according to Xavier and Xavier (1999) and Farias et al. (2012). Another technique used constantly is the Rainfall Anomaly Index (RAI) adopted in the studies (Freitas, 2004; 2005; Araújo et al., 2009; Silva et al., 2010).

The use of RAI has proved to be an important tool in precipitation analysis, considering its procedural simplicity, due to computational resources and the qualitative determination of extreme anomalies (Sanches, 2014).

The analysis of climatic variability is relevant when analyzing the impacts of climate in areas of socioeconomic and environmental interest (Noronha et al., 2016). Thus, through these studies, it becomes possible to know the problems of the region, promoting the adequate planning of environmental management (Silva et al., 2010).

The techniques of remote sensing with the use of satellite images allow to identify a greater detail in the studies on meteorological phenomena. These techniques with the implementation of algorithms, highlighting the SEBAL, are important in the determination of biophysical parameters that identify the different uses and occupations of the soil in the diverse ecosystems of the terrestrial globe.

Pacheco et al. (2014) points out that there is a growing need to know the physical processes that involve the energy and mass changes between the surface and the atmosphere, changes that depend on the use and coverage of the soil. The physical and quantitative understanding of these processes, through orbital images, can help in the management and conservation of the environment, minimizing the negative impacts resulting from the inadequate use of natural resources.

Gusmão et al. (2012) emphasizes that the possibility of identifying changes occurring on the earth's surface resulting from natural and / or anthropic phenomena, many of which can be diagnosed from the monitoring of radiative surface changes, is increasingly evident.

One of biophysical parameters most commonly used in environmental monitoring is the surface albedo, important in environmental studies at detecting changes in the Earth's surface such as desertification, forest fires and changes in local climate (Silva et al., 2005).

In ecological systems albedo indicates the state of microclimatic conditions of agricultural crops and the absorption of radiation, affecting physical and physiological aspects, such as energy balance, evapotranspiration, photosynthesis and respiration (Wang et al., 2001).

Normalized Difference Vegetation Index (NDVI) is another relevant and widely used parameter in studies on land use and occupation. Ponzoni (2012) says that NDVI is used to monitor vegetation, supporting the construction of seasonal and temporal profiles of vegetation activities, such as duration of growth period, green peak, physiological changes of leaves and senescence periods, interannual comparisons of these profiles.

In this context, the objective of this study was to identify extreme precipitation events and to evaluate biophysical parameters by remote sensing using orbital images between 1986 and 2016.

\section{Materials and methods}

The study area is located in the micro region of Sertão do Pajeú in the State of Pernambuco (Figure 1) and with an extension of $2980 \mathrm{~km}^{2}$ (IBGE, 2016). Serra Talhada is characterized by a semiarid climate, hot and dry, with an average annual temperature above $30{ }^{\circ} \mathrm{C}$ and rainfall in the range of $400-800 \mathrm{~mm}$ per year, with summer rains that fall into the autumn. The rainy season starts in November and runs through April (CPRM, 2005).

A historical series of 31 years of meteorological precipitation data between 1986 and 2016 were generated by the Pernambuco State Agency for Water and Climate (APAC). The weather station (code 13) was chosen because it has a historical series with fewer faults, so, to correct these, other city stations were used to form pairs of months by linear regression through Software Statistica 10. We analyzed 372 months, where 39 had failures, so that only the years 1988 and 1992 add up to 22 months of failure. 


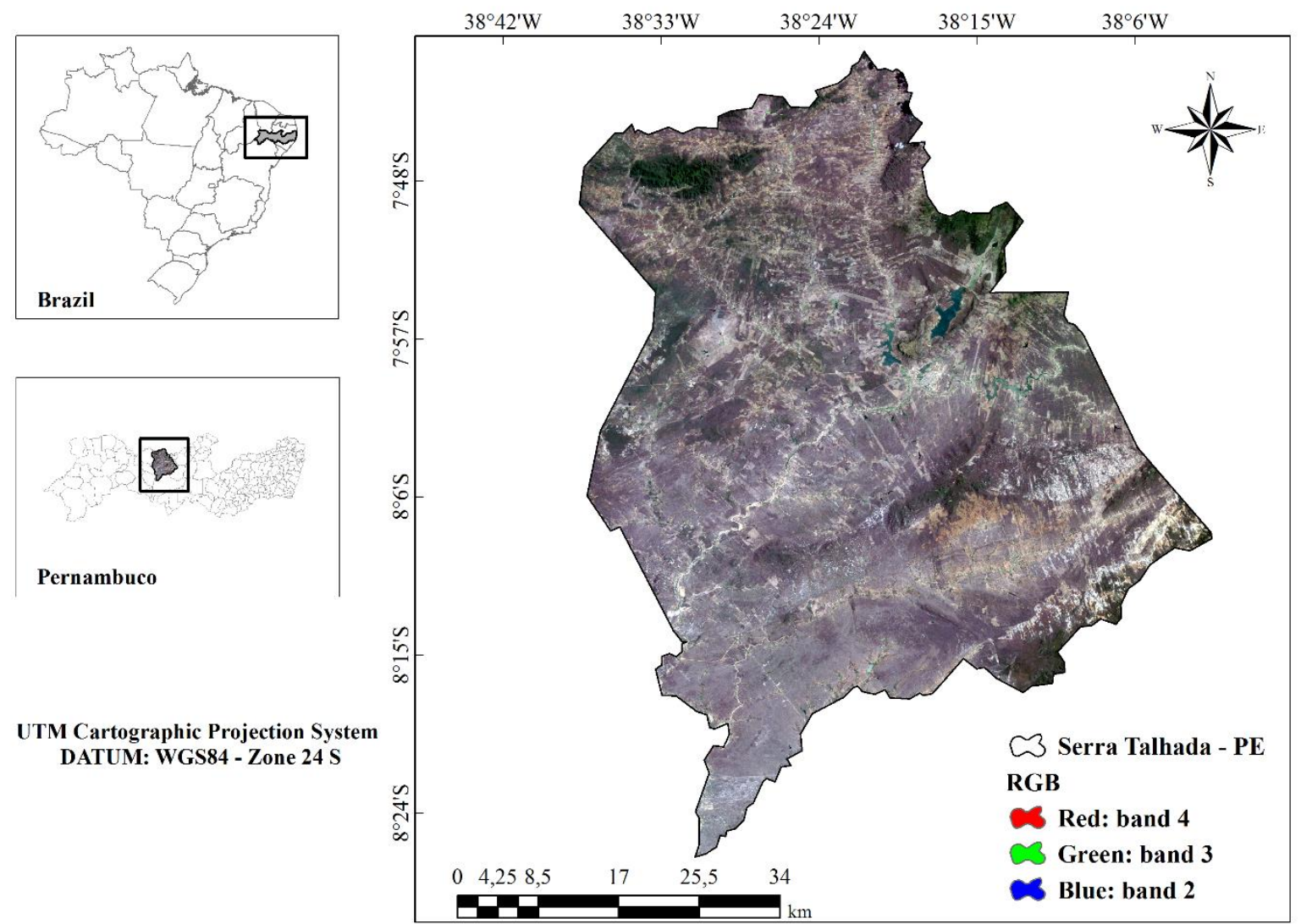

Figure 1 - Spatial map of the location of the municipality of Serra Talhada, Pernambuco, Brazil in the composition of natural color: RGB-321, Landsat 5, 26/09/1989.

Surface data were collected through meteorological stations such as instantaneous air temperature $\left(\mathrm{T}_{\mathrm{ar}},{ }^{\circ} \mathrm{C}\right)$, maximum $\left(\mathrm{T}_{\mathrm{x}}\right)$ and minimum $\left(\mathrm{T}_{\mathrm{N}}\right)$; Relative humidity of the instantaneous air (UR, \%), maximum (URx) and minimum $\left(\mathrm{UR}_{\mathrm{N}}\right) ;\left(\mathrm{P}_{\mathrm{o}}, \mathrm{kPa}\right)$ of the Data Collection Platform (DCP), West Longitude: 38,287 , Altitude: $430 \mathrm{~m}$. Surface data is extremely necessary to perform corrections and calibrations on images.

The Quantile technique proposed by Pinkayan (1966) and disseminated in Brazil by Xavier and Xavier (1999); this is a simple technique to analyze the occurrences of dry and rainy years. $\mathrm{O}(\mathrm{Qp})$ by definition is a limit of the quantile interval for a given random variable $(X)$, where $(p)$ is the probability of occurrence, such that $(\mathrm{X})$ is less than $(\mathrm{Qp})$. Thus, the interval chosen and associated with the quantile should satisfy the following relation (Xavier et al., 2002):

$$
\operatorname{Prob}(X \leq Q p)=p
$$

Based on Pinkayan (1966) and Xavier and Xavier (1999) this work adopted quantlics orders $\mathrm{p}=$ $0.15 ; 0.35 ; 0.65$ and 0.85 for the purpose of classifying the annual precipitations in very dry, dry, normal, rainy and very rainy classes, as shown in Table 1. 
Table 1 - Determination of the classes, probabilities and average interval of precipitation per year, related to the quantile orders.

\begin{tabular}{cccc}
\hline Classes & Quantile & \multicolumn{2}{c}{ Average precipitation interval } \\
& & Minimum & Maximum \\
\hline Very dry & $\mathrm{P}<\mathrm{Q}_{0.15}$ & 217.4 & 418.5 \\
Dry & $\mathrm{Q}_{0.15} \leq \mathrm{Q}_{0.35}$ & 450.4 & 583 \\
Normal & $\mathrm{Q}_{0.35} \leq \mathrm{Q}_{0.65}$ & 596.6 & 690.8 \\
Rainy & $\mathbf{Q}_{0.65} \leq \mathrm{Q}_{0.85}$ & 715.2 & 818.57 \\
Very rainy & $\mathrm{P}>\mathrm{Q}_{0.85}$ & 823.9 & 1140 \\
\hline
\end{tabular}

Another parameter used to detect and classify dry and rainy years was the Rainfall Anomaly Index (RAI) proposed by Rooy (1965) and adopted by Freitas (2004). The calculation to obtain the positive and negative anomalies, was used the following equations 1 and 2 respectively:

$$
\mathrm{RAI}=3 \frac{\mathrm{p}-\mathrm{p}_{\text {med }}}{\mathrm{p}_{\max }-\mathrm{p}_{\text {med }}}
$$

$$
\mathrm{RAI}=3 \frac{\mathrm{p}-\mathrm{p}_{\mathrm{med}}}{\mathrm{p}_{\min }-\mathrm{p}_{\text {med }}}
$$

Where,

$\mathrm{P}=$ current annual precipitation $(\mathrm{mm}) ; \mathrm{P}_{\text {med }}=$ mean annual rainfall of the historical series $(\mathrm{mm}) ; \mathrm{P}_{\max }=$ mean of the ten largest annual precipitations of the historical series $(\mathrm{mm})$ and $\mathrm{P}_{\min }=$ mean of the ten lowest annual precipitations of the historical series $(\mathrm{mm})$.

The classification of the dry and humid years was based on the methodology of Araújo et al. (2009), explained in Table 2.

Table 2 - Intensity Classification of Rainfall Anomalies Index.

\begin{tabular}{ccc}
\hline & RAI rank & Intensity Classification \\
\cline { 2 - 3 } Rainfall Anomalies Index & $\geq 4$ & Extremely humid \\
(RAI) & 2 to 4 & Very humid \\
& 0 to 2 & Humid \\
& 0 to -2 & Dry \\
& -2 to -4 & Very dry \\
& $\leq-4$ & Extremely dry \\
\hline
\end{tabular}

They were also used satellite images Landsat 5 TM (Thematic Mapper), acquired United States Geologial Survey - USGS / NASA. The orbital images of the TM sensor are composed of 7 spectral bands between the wavelengths: $0.452-12.42 \mu \mathrm{m}$, with spatial resolution of $30 \mathrm{~m}$ (bands 1 to 5 and 7) and $120 \mathrm{~m}$ (thermal band 6). The chosen images had as their goal to meet the lowest cloud presence $(<10 \%)$, in order to avoid underestimating or overestimating the values found.
The imaging dates were: 09/26/1989 and 09/19/1998, through the SEBAL algorithm the parameters were processed, where it was initially necessary to stack the bands from 1 to 5 and 7 . The images of the area were then georeferenced. The UTM (Universal Transverse Mercator) Cartographic Projection System was DATUM: WGS 1984, used for Zone 24 S, and ERDAS IMAGINE ${ }^{\circledR} 9.1$ software was used to implement this algorithm, conformed Bastiaanssen et al. (1998) and Allen et al. (2002). 
The first step was the conversion of gray levels to spectral radiance according to the calibration coefficients (minimum radiance - Lmin and maximum Lmax) and spectral solar irradiances of each band $(\mathrm{kb}$
Land 5) at the Top of the Atmosphere (TOA) determined by Chander and Markham (2003). Table 3 presents the description of the bands of the Thematic Mapper and their respective wavelengths $(\mu \mathrm{m})$.

Table 3 - Landsat 5 (TM) calibration coefficients.

\begin{tabular}{|c|c|c|c|c|}
\hline \multirow{2}{*}{ wave } & \multirow{2}{*}{ wavelengths $(\mu \mathrm{m})$} & \multicolumn{2}{|c|}{$\begin{array}{l}\text { Calibration coefficients } \\
\qquad\left(\mathrm{Wm}^{-2} \mathbf{s r}^{-1} \mu \mathbf{m}^{-1}\right)\end{array}$} & \multirow{2}{*}{$\begin{array}{l}\text { Spectral Radiance at } \\
\text { the Atmosphere Top } \\
\qquad\left(\mathrm{W} \mathbf{m}^{-2} \mu \mathrm{m}^{-1}\right)\end{array}$} \\
\hline & & $\mathbf{a}$ & $\mathbf{b}$ & \\
\hline 1 (Blue) & $0.452-0.518$ & -1.52 & 152.10 & 1957 \\
\hline 2 (Green) & $0.528-0.609$ & -2.84 & 29681 & 1826 \\
\hline 3 (Red) & $0.626-0.693$ & -1.17 & 204.30 & 1554 \\
\hline 4 (Near infrared) & $0.776-0.904$ & -1.51 & 206.20 & 1036 \\
\hline 5 (Infrared medium) & $1.567-1.784$ & -0.37 & 27.19 & 215 \\
\hline 7 (Infrared medim) & $2.097-2.349$ & -0.15 & 14.38 & 80.67 \\
\hline
\end{tabular}

The determination of the spectral irradiance of each band using equation (3) according to Chander et al. (2009).

$$
\mathrm{L}_{\mathrm{b}}=\mathrm{a}_{\mathrm{b}}+\left(\frac{\mathrm{b}_{\mathrm{b}}-\mathrm{a}_{\mathrm{b}}}{254}\right)\left(\mathrm{ND}_{\mathrm{b}}-1\right)
$$

Where, $\mathrm{L}_{\mathrm{b}}\left(\mathrm{W} \mathrm{m}^{-2} \mathrm{sr}^{-1} \mu \mathrm{m}^{-1}\right)$ is the radiance of each pixel; b (subscript) represents each Landsat 5 TM wave; a and $\mathrm{b}$ are the minimum and maximum spectral radiances respectively ( $\mathrm{W} \mathrm{m}^{-2} \mathrm{sr}^{-1} \mu \mathrm{m}^{-1}$, Table 3 ); $\mathrm{ND}$ is the pixel intensity (Digital number - integer 0 to 255 ).

The reflectance was determined as a function of the sun angle and the ratio of the Earth-Sun astronomical distance, according to equation 4 (Chander et al., 2009).

$$
r_{b}=\frac{\pi \times L_{b}}{k_{b} \times \operatorname{Cos} Z \times d_{r}}
$$

Where, $r_{b}\left(\mathrm{~W} \mathrm{~m} \mathrm{~m}^{-2} \mathrm{sr}^{-1} \mu \mathrm{m}^{-1}\right)$ is the monochromatic reflectance of each pixel in each wave (b); $\left(\mathrm{W} \mathrm{m}^{-2} \mu \mathrm{m}^{-1}\right)$ is the solar constant, as proposed by Chander et al. (2009); Cos (Z) is the local solar zenith angle; dr is the inverse of the square of the relative Earth-Sun distance.

The calculation of the planetary albedo $\left(\alpha_{\text {toa }}\right)$ (not adjusted to the atmospheric transmissivity) was obtained by the linear combination of the monochromatic reflectance in each of the reflective band of 1 to 5 and 7 of the Landsat TM, according to Bezerra et al. (2014), equation 5.

$$
\begin{aligned}
& \alpha_{\text {toa }}=0.293 \times \mathrm{r}_{1}+0.274 \times \mathrm{x}_{2}+0.233 \times \mathrm{r}_{3}+0.157 \mathrm{x} \\
& \mathrm{r}_{4}+0.033 . \mathrm{r}_{5}+0.011 \mathrm{x} \mathrm{r}_{7}
\end{aligned}
$$

Where: $r_{1}, r_{2}, r_{3}, r_{4}, r_{5}, r_{7}$ are the planetary reflections of the respective bands.

The surface albedo or corrected albedo $\left(\alpha_{\text {sup }}\right)$ was determined according to Allen et al. (2002) using equation 6 , applicable for clear sky days.

$$
\alpha_{\text {sup }}=\frac{\alpha_{\text {toa }-} \alpha_{\text {atm }}}{\tau_{\mathrm{sw}}^{2}}
$$

Where: $\alpha_{\text {toa }}$ is the planetary albedo of each pixel or albedo without atmospheric correction; $\alpha_{\text {atm }}$ is the reflectance of the atmosphere itself (for the SEBAL model the value of 0.03 has been recommended) and $\tau_{\mathrm{sw}}$ is the atmospheric transmission in the field of solar radiation for days of clear sky, according Allen et al. (2002) as described in equation 7.

$$
\begin{aligned}
& \tau_{\mathrm{sw}}=0.35+0.627 \times \operatorname{exp~x} \\
& {\left[\frac{-0.00146 \times \mathrm{P}_{\mathrm{o}}}{\mathrm{K}_{\mathrm{t}} \times \cos \theta}-0.075\left(\frac{\mathrm{W}}{\cos \theta}\right)^{0.4}\right]}
\end{aligned}
$$

Where: $P_{o}(\mathrm{kPa})$ is the instantaneous atmospheric pressure; the coefficient of turbidity of the atmosphere $\left(\mathrm{K}_{\mathrm{t}}\right)$ for this work was the value $1\left(\mathrm{~K}_{\mathrm{t}}=1.0\right.$ for clear sky and $\mathrm{K}_{\mathrm{t}}=0.5$ for extremely covered and/or polluted air, Allen et al., 2002); W (mm) is the water precipitated as a function of the relative humidity of the instantaneous 
air, this was estimated according to equation 8 (Garrison \& Adler 1990):

$\mathrm{W}=0.14 \times \mathrm{e}_{\mathrm{a}} \times \mathrm{P}_{\mathrm{o}}+2.1$

Where: $\mathrm{e}_{\mathrm{a}}(\mathrm{kPa})$ is the actual atmospheric water vapor pressure, calculated using meteorological data according to equation 9:

$$
\mathrm{e}_{\mathrm{a}}=\frac{\mathrm{UR \times \textrm {e } _ { \mathrm { s } }}}{100}
$$

Where: $e_{s}(\mathrm{kPa})$ is the saturation pressure of the water vapor, Equation 10.

$$
\mathrm{e}_{\mathrm{s}}=0.6108 \times \exp \left(\frac{17.27 \times \mathrm{T}_{\mathrm{ar}}}{237.3 \times \mathrm{T}_{\mathrm{ar}}}\right)
$$

Where: $\mathrm{T}_{\mathrm{a}}$ is the air temperature $\left({ }^{\circ} \mathrm{C}\right)$.

O Normalized Difference Vegetation Index (NDVI) is a sensitive indicator of the amount of green vegetation and also of its condition, where its values vary between -1 and 1 . The NDVI was obtained according to Allen et al. (2002) and Bezerra et al. (2014), equation 11.

$$
\mathrm{NDVI}=\frac{\mathrm{r}_{\mathrm{b} \text { IR }}-\mathrm{r}_{\mathrm{bR}}}{\mathrm{r}_{\mathrm{b} \text { IR }}+\mathrm{r}_{\mathrm{bR}}}
$$

Where: $\mathrm{r}_{\mathrm{b}}$ IR and $\mathrm{r}_{\mathrm{b}}$ correspond to the reflective bands 4 and 3 of the TM sensor, respectively.

The methods presented were statistically analyzed whit the measures of central tendency and dispersion, calculated in ERDAS IMAGINE ${ }^{\circledR} 9.1$
Software. The ArcGIS ${ }^{\circledR}$ 10.2.2 was used to prepare the thematic maps. The coefficient of variation $(\mathrm{CV})$ was analyzed according to Warrick \& Nielsen (1980).

\section{Results and discussion}

The annual precipitation of the municipality of Serra Talhada by the technique of Quantiles varied between $217.4 \mathrm{~mm}$ and $1140 \mathrm{~mm}$ (Table 4). The years classified as very dry were 1993, 1998, 2012, 2016. In the year 1998 with the occurrence of El niño, it presented the lowest rainfall with a mean of $289 \mathrm{~mm}$. The very rainy years were 1988, 1989, 2004 and 2011, in which the year 1989 was present the occurrence of the phenomenon La niña. According to Duarte et al. (2015) the year of 1998 presented as very dry and the year of 1989 as a year Extremely rainy for the same semiarid region.

It can be verified that the years classified as normal have an average of $644.01 \mathrm{~mm}$ and was found within the standards for region. Another relevant result that shows interannual rainfall variability in the semiarid was in the years 2011 calsificado as very rainy and 2012 was very dry. Studies in Petrolina-PE presented very rainy classification in the years 1989 and 2004, and in 1993 and 2012 were very dry (Lopes et al., 2015). Farias et al. (2012) also using the Quantile technique emphasized the occurrence of extremely dry and rainy events at points located in the Sertão mesoregion in Pernambuco, three of them presenting a predominance of extremely dry, with 52 occurrences of dry events and 35 occurrences for the rainy ones, for a series of data from 1979 to 2010.

Table 4 - Classification of the historical profile of precipitation by the values of each pluviometric regime established for the municipality of Serra Talhada (1986 - 2016).

\begin{tabular}{lccccccccc}
\hline \multicolumn{2}{c}{ Very dry } & \multicolumn{2}{c}{ Dry } & \multicolumn{2}{c}{ Normal } & \multicolumn{2}{c}{ Rainy } & \multicolumn{2}{c}{ Very rainy } \\
\hline Year & Precipitation & Year & Precipitation & Year & Precipitation & Year & Precipitation & Year & Precipitation \\
\hline 1993 & 295.7 & 1990 & 519.75 & 1987 & 599 & 1986 & 818.57 & 1988 & 892.69 \\
1998 & 217.4 & 1991 & 486.75 & 1992 & 690.8 & 1994 & 734 & 1989 & 1140 \\
2012 & 224.4 & 1999 & 5209 & 1995 & 673.45 & 1996 & 734.3 & 2004 & 823.9 \\
2016 & 418.5 & 2000 & 559 & 2002 & 598.4 & 1997 & 758.8 & 2011 & 866.4 \\
& & 2001 & 583 & 2006 & 661.1 & 2003 & 814.73 & & \\
& 2013 & 450.4 & 2008 & 675.6 & 2005 & 715.2 & & \\
& & 2015 & 466.6 & 2009 & 688.3 & 2007 & 747.6 & & \\
\multicolumn{2}{l}{} & & & 2010 & 612.9 & & & & \\
Average & 289 & & 512.34 & & 644.012 & & 760.46 & & \\
CV (\%) & 32.28 & & 150.27 & & 6.41 & & 5.34 & & \\
\hline
\end{tabular}


Rainfall Anomalies Index found that 16 years presented positive indexes and 15 negative years, ranging from -7.17 to 8.25 in the RAI classification range (Figure 2). The years 1993, 1998 and 2012 were classified as extremely dry, corroborating with the Quantile technique, except 2016, which was considered as very dry. Only in 1989 it obtained a classification of extremely humid, the years of 1986, 1988, 2003, 2004 and 2011 were in the range of very humid. The years considered very dry were 1991, 2013, 2015 and 2016.

In other papers, reporting on the use of a historical series between 1950 and 2009, Nóbrega and Santiago (2014) noted that Serra Talhada had its levels of precipitation severely altered by the occurrence of El Ninõ (1993 and 1998) corroborating this study for the year of 1998, classified as extremely dry, within another historical series of data.

Sousa et al. (2013) working on the Jaguaribe river watershed in the state of Ceará, used a series of historical precipitation data between 1921 and 2010, found that the predominance of dry years occurs throughout the hydrographic unit. The value of $\mathrm{CV}$ presented for each classification as low (Rainy), average (very dry and very rainy) and high variability (dry), according to the criteria of Warrick and Nielsen (1980).

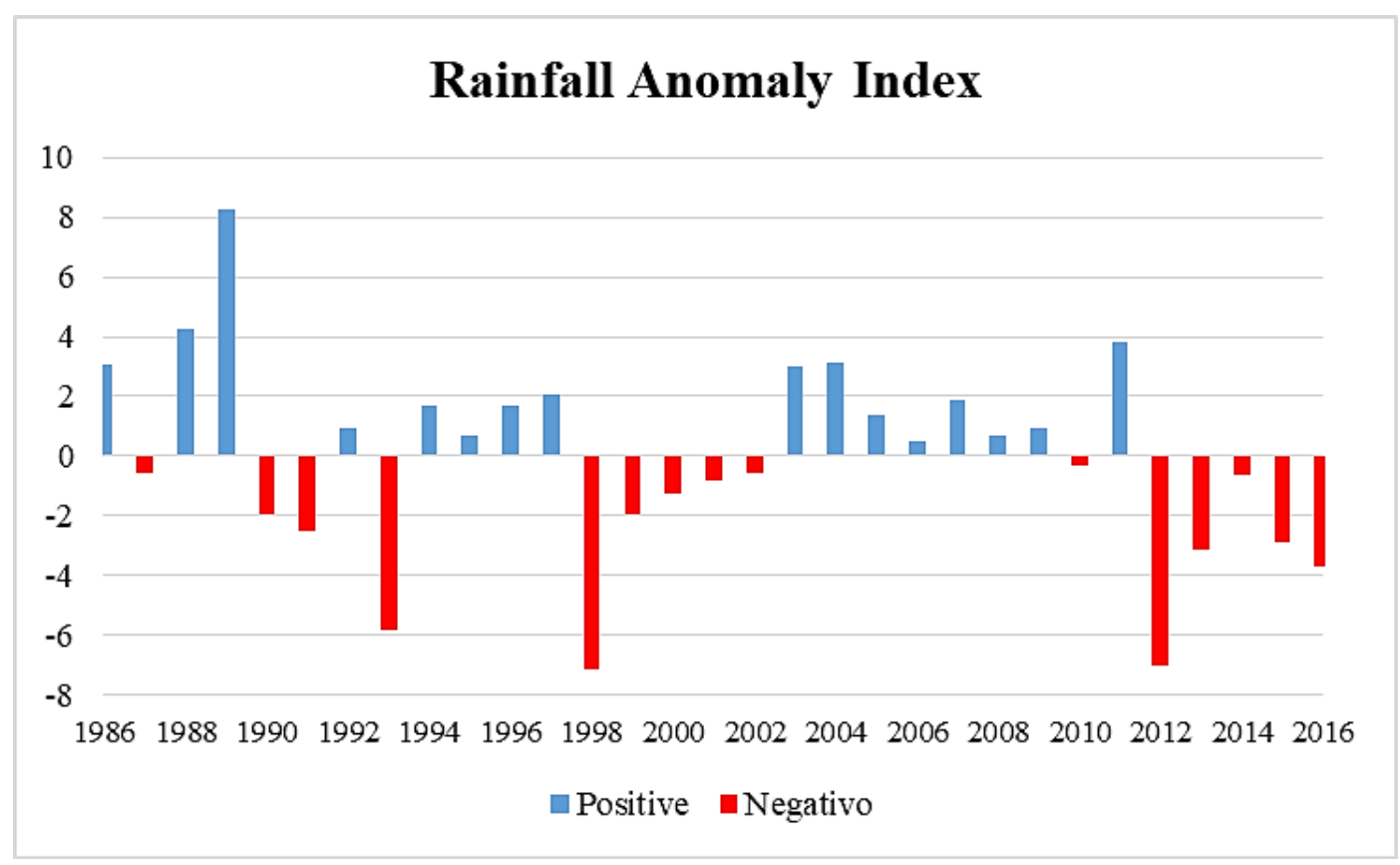

Figure 3 - Rainfall Anomaly Index (1986-2016) from Serra Talhada, Pernambuco.

The surface albedo on day of imaging (26/09/1989) presented the map with values varying between 0.03 and 0.51 (Figure $3 \mathrm{~A}$ ) and with a mean of 0.15 (Table 5). For the 19/09/1998 (Figure 4A) presented minimum and maximum values ranging from 0.03 to 0.55 , respectively, and a mean of 0.18 (Table 5). Although the two dates have years with extreme events, these had not differences, probably because are of the same dry period.

The NDVI of day 26/09/1989 presented the map with values ranging from -0.52 to 0.77 (Figure $3 \mathrm{~B}$ ) and a mean of 0.309 (Table 5). The 19/09/1998 (Figure 4B) found similar responses with the previous date, as described in Table 5, this is explained by being the same dry period. In the year of 1989 it was observed an increase in the average value of NDVI explained by the rains of previous months. It has been reported by the Caatinga biome, which is characterized by its resilience power, with accelerated vegetative growth in the presence of rainfall (Rodrigues et al., 2009; Arraes et al., 2012). Table 5 presents the statistical values referring to the images, where it is possible to highlight the values of $\mathrm{CV}$, which had a mean variability, according to the criteria of Warrick and Nielsen (1980). 


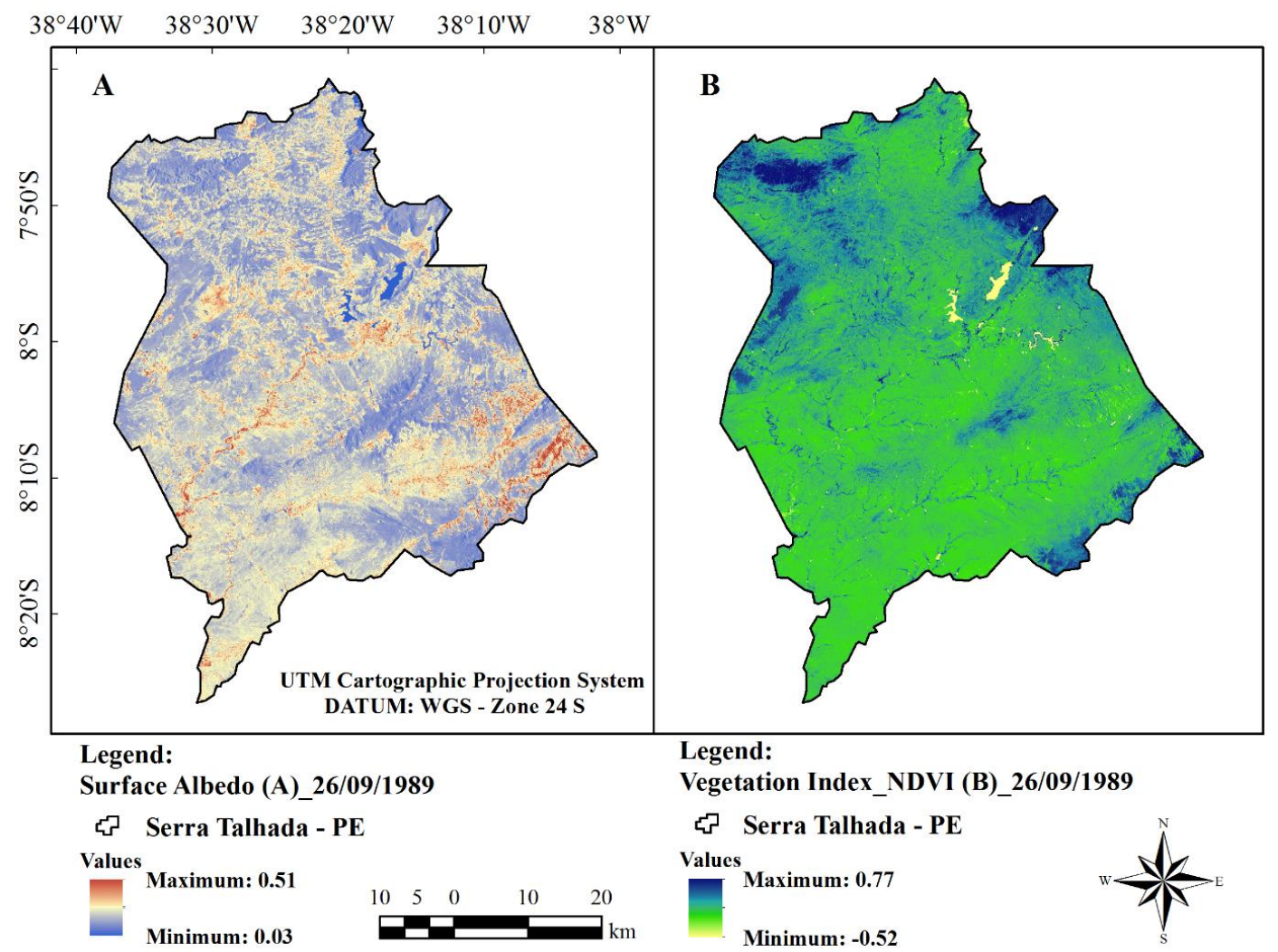

Figure 3 - Thematic Map of Surface Albedo (A) and vegetation index: NDVI (B) for the municipality of Serra Talhada, Pernambuco (26/09/1989).

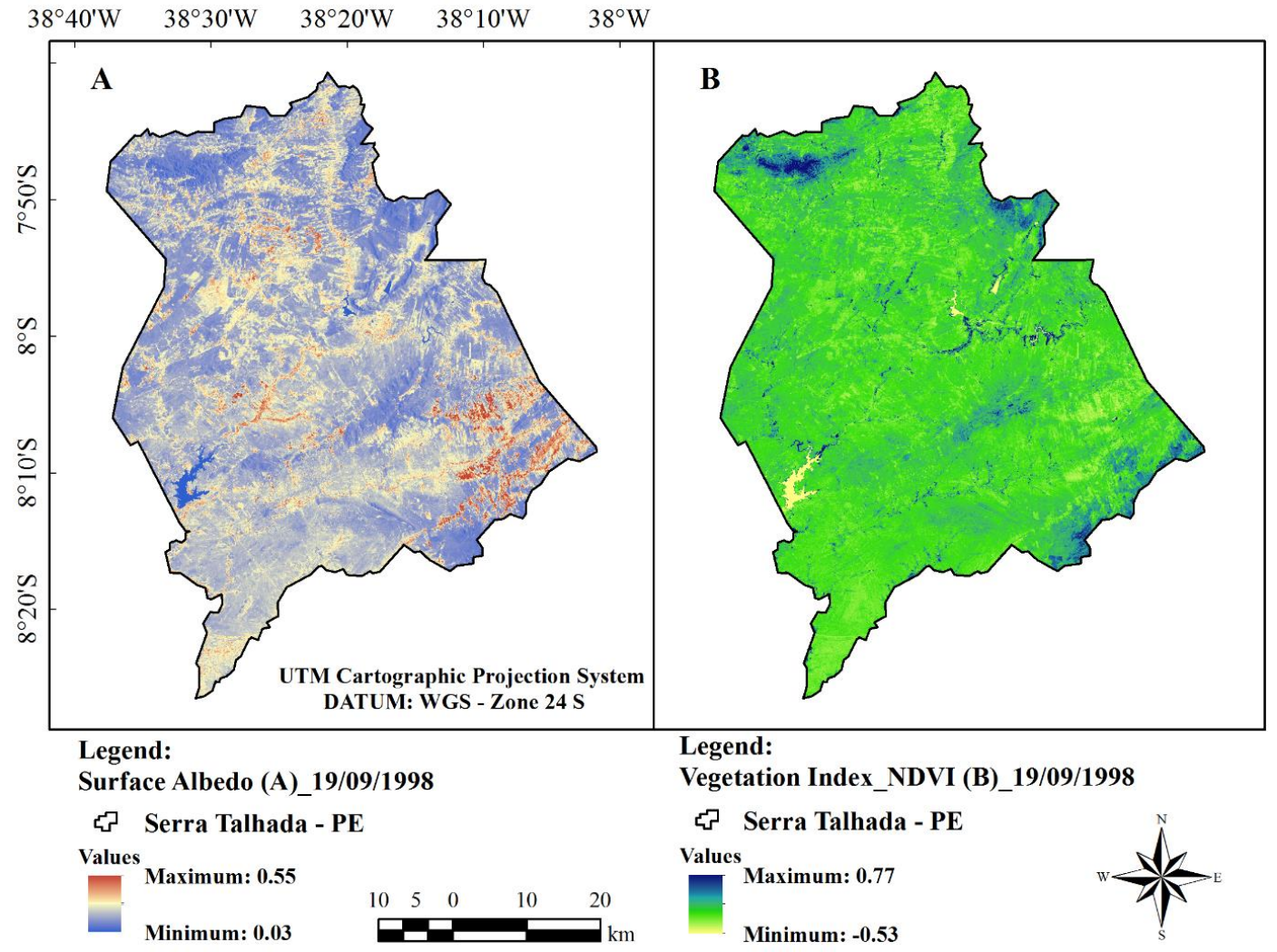

Figure 4 - Thematic Map of Surface Albedo (A) and vegetation index: NDVI (B) for the municipality of Serra Talhada, PE (19/09/1998). 
Table 5 - Descriptive and variation statistics from biophysical parameters.

\begin{tabular}{ccccccccc}
\hline $\begin{array}{c}\text { Biophysical } \\
\text { parameters }\end{array}$ & Dates & Minimum & Maximum & Average & Median & Mode & $\begin{array}{c}\text { Standard } \\
\text { deviation }\end{array}$ & $\begin{array}{c}\text { CV } \\
(\%)\end{array}$ \\
\hline Albedo & $26 / 09 / 1989$ & 0.03 & 0.51 & 0.154 & 0.148 & 0.139 & 0.032 & 21 \\
NDVI & $26 / 09 / 1989$ & -0.52 & 0.77 & 0.309 & 0.284 & 0.249 & 0.098 & 32 \\
Albedo & $19 / 09 / 1998$ & 0.03 & 0.55 & 0.187 & 0.177 & 0.168 & 0.052 & 28 \\
NDVI & $19 / 09 / 1998$ & -0.53 & 0.77 & 0.184 & 0.175 & 0.165 & 0.055 & 30 \\
\hline
\end{tabular}

In December 2000 and October 2001, Silva and Bezerra (2006) observed images of Landsat 5 TM from the semi-arid region of areas with irrigated fruit trees and native vegetation typical of the caatinga biome and found an average albedo value of 0.22 , and Bezerra et al. (2014) found surface albedo ranging from 0.10 to 0.35 for the semi-arid region of Rio Grande do Norte. The highest values found during the dry season in the areas of exposed soil ( 0.30 to 0.35 ), but in general the authors observed that the areas with vegetation cover of caatinga presented albedo in the range of 0.10 to 0.15 .

Bezerra et al. (2014) também encontraram, para o NDVI valores entre 0,10 e 0,26 durante o período seco, enquanto para o chuvoso os valores variaram entre 0,66 e 0,79 , corroborando o presente estudo.

In general, these results were consistent with those presented in the basic literature, proving the good applicability of the parameters used in the semi-arid region, and could subsidize public policies for the reversal and management of the semiarid natural resources.

\section{Conclusions}

The Quantile technique allowed the classification of annual precipitations, and showed the interannual variability of the precipitation, possibly indicating that the meteorological responses were particularly characteristic of the semiarid. The Rainfall Anomaly Index the extreme events of precipitation allowed to identify the phenets of the El Niño phenomenon in the years of 1989 and 1998.

The use of remote sensing as a tool to investigate land use and occupation helped to monitor and identify environmental changes in the region, e.g. the surface albedo ratio and the normalized difference vegetation index, showed differences between spatial and temporal patterns, caused by local climatic variations and anthropic activities.

\section{Acknowledgments}

To the Univesidade Federal Rural de Pernambuco (UFRPE); Programa de Pós-Graduação em Engenharia Agrícola (PGEA); Coordenação de Aperfeiçoamento de Pessoal de Nível Superior (CAPES), the granting of the postgraduate scholarship and the Intituto Nacional de Meteorologia (INMET) for assigning meteorological data.

\section{References}

Allen, R.G., Tasumi, M., Trezza, R., Waters, R., Bastiaanssen, W., 2002. SEBAL (Surface Energy Balance Algorithms for Land). Advance Training and Users Manual - Idaho Implementation, version 1.0. University of Idaho, Idaho.

Araújo, L.E., Moraes Neto, J.M., Sousa, F.A.S., 2009. Análise Climática da Bacia do Rio Paraíba - Índice de Anomalia de Chuva (IAC). Engenharia Ambiental, Espírito Santo do Pinhal 6, 508-523.

Arraes, F.D.D., Andrade, E.M., Silva, B.B., 2012. Dinâmica do balanço de energia sobre o açude Orós e suas adjacências. Revista Caatinga 25, 119-127.

Bastiaanssen, W.G.M., Pelgrum, H., Wang, J., Ma, Y., Moreno, J.F., Roerink, G.J., Van der Wal, T., 1998. A remote sensing surface energy balance algorithm for land (SEBAL). Part 2: Validation. Journal of hydrology 212, 213-229.

Bezerra, J.M., Moura, G.B.A., Silva, B.B., Lopes, P.M.O., Silva, E.F.F., 2014. Parâmetros biofísicos obtidos por sensoriamento remoto em região semiárida do estado do Rio Grande do Norte, Brasil. Revista Brasileira de Engeharia Agrícola e Ambiental 18, 73-84.

Chander, G., Markham, B.L., Helder, D.L., 2009. Summary of current radiometric calibration coefficients for Landsat MSS, TM, ETM+, and EO1 ALI sensors. Remote Sensing of Environment 113, 893-903. 
Chander, G., Markhan, B., 2003. Revised Landsat 5 TM radiometric calibration procedures and post calibration dynamic ranges. IEEE Transactions on Geosciences and Remote Sensing 41, 2674-2677.

CPRM. Serviço Geológico do Brasil, 2005. Projeto cadastro de fontes de abastecimento por água subterrânea: Diagnostico do município de Serra Talhada. CPRM/PRODEEM, Recife.

Duarte, C.C., Nóbrega, R.S., Coutinho, R.Q., 2015. Análise Climatológica e dos eventos extremos de chuva no município de Ipojuca, Pernambuco. Revista de Geografia 32, 158-176.

Farias, R.F.L, Alves, K.M.A.S., Nóbrega, R.S., 2012. Climatologia da ocorrência de eventos extremos de precipitação na mesorregião do Sertão Pernambucano. Revista Geonordeste (Edição Especial 2) 1, 930-941.

Freitas, M.A.S., 2004. A Previsão de Secas e a Gestão Hidroenergética: O Caso da Bacia do Rio Parnaíba no Nordeste do Brasil. Seminário Internacional sobre Represas y Operación de Embalses, Puerto Iguazú.

Freitas, M.A.S., 2005. Um Sistema de Suporte à Decisão para o Monitoramento de Secas Meteorológicas em Regiões Semi-Áridas. Revista Tecnologia. Suplem, 84-95.

Garrison, J.D., Adler, G.P., 1990. Estimation of precipitable water over the United State for aplication to the division of solar radiation into its direct and difuse coponents. Solar Energy 44, 225241.

Gusmão, A.C.V.L., Silva, B.D., Montenegro, S.M.G.L., Galvincio, J.D., 2012. Determinação do saldo radiativo na Ilha do Bananal, TO, com imagens orbitais. Revista Brasileira de Engenharia Agrícola e Ambiental 16, 1107-1114.

Lopes, I., Guimarães, M.J.M., Melo, J.M.M., 2015. Análise da precipitação da estação da embrapa semiárido, projeto bebedouro Pretolina/PE, através da técnica de Quantis. Workshop Internacional Sobre Água no Semiárido Brasileiro. Campina Grande.

Marengo, J.A., Alves, L.M., Beserra, E.A., Lacerda, F.F., 2011. Recursos hídricos em regiões áridas e semiárida: Variabilidade e mudanças climáticas no semiárido brasileiro. Instituto Nacional do Semiárido $13,383-422$.

Nobre, P., 2011. Mudanças Climáticas e Desertificação: os desafios para o estado brasileiro. Desertificação e Mudanças climáticas no Semiárido Brasileiro. Módulo 1. INSA- Instituto Nacional do Seminário, Campina Grande.

Nóbrega, R.S., Santiago, G.A.C.F., 2014. Tendência de temperatura na superfície do mar nos oceanos atlântico e pacífico e variabilidade de precipitação em Pernambuco. Mercator 13, 107-118.

Noronha, G.C., Hora, M.A.G.M., Silva, L.P., 2016. Análise do Índice de Anomalia de Chuva para a Microbacia de Santa Maria/Cambicó, RJ. Revista Brasileira de Meteorologia 31, 74-81.

Pacheco, A.P., Lucas, A.A., Silva, B.B., Mariano, G., 2014. Desertificação: Contextualização e Sensoriamento Remoto. Estudos Geológicos 24, 109-126.

Pinkayan, S., 1966. Conditional Probabilities of Occurence of Wet and Dry Years over a Large Continental Area; Hydrology Papers, Number 12, Colorado State University, Fort-Collins, Col., U.S.A.

Ponzoni, F.J., 2012. Sensoriamento Remoto da Vegetação. 2. ed. Oficina de Textos, São Paulo.

Rodrigues, J.O., Andrade, E., Teixeira, A.S., Silva, B.B., 2009. Sazonalidade de variáveis biofísicas em regiões semiáridas pelo emprego de sensoriamento remoto. Revista Brasileira de Engenharia Agrícola e Ambiental 29, 452-465.

Rooy, M.P.V., 1965. A rainfall anomaly index independent of time and space. Weather Bureau of South Africa 14, 43-48.

Sanches, F.O., Verdum, R., Fisch, G., 2014. O índice de anomalia de chuva (IAC) na avaliação das precipitações anuais em Alegrete/RS (1928-2009). Caminhos de Geografia 15, 73-84.

Silva, B.B., Bezerra, M.V.C., 2006. Determinação dos fluxos de calor sensível e latente na superfície utilizando imagens TM Landsat 5. Revista Brasileira de Agrometeorologia 14, 174-186.

Silva, B.B., Lopes, G.M., Azevedo, P.V., 2005. Determinação do albedo de áreas irrigadas com base em imagens Landsat 5 TM. Revista Brasileira de Agrometeorologia 13, 201-211.

Silva, D.F., Souza, F.A.S., Kayano, M.T., 2010. Escalas temporais da variabilidade pluviométrica na bacia hidrográfica do rio Mundaú. Revista Brasileira de Meteorologia 25, 324-332.

Sousa, A.B., Melo, R.A., Silva, D.F.A., 2013. Avaliação climática e dos recursos hídricos da bacia hidrográfica do rio Jaguaribe (CE). Revista Brasileira de Geografia Física 6, 1115-1140.

Wang, S., Grant, R.F., Verseghy, D.L., Black, T.A., 2001. Modelling plant carbon and nitrogen dynamics of a boreal aspen forest in CLASS - the Canadian Land surface Scheme. Ecology Modelling 142, 135154.

Warrick, A.W., Nielsen, D.R., 1980. Spatial variability of soil physical properties in the field. In: Hillel, D. (ed.). Applications of Soil Physics. Academic, 
New York.

Xavier, T.M.B.S, Xavier, A.F.S., 1999. Caracterização de períodos secos ou excessivamente chuvosos no estado do Ceará através da técnica dos Quantis: 1964-1998. Revista Brasileira de Meteorologia 14, 63-78.
Xavier, T.M.B.S., Silva, J.F., Rebello, E.R.G.A., 2002. Técnica dos Quantis e suas aplicações em Meteorologia, Climatologia e Hidrologia, com ênfase para as regiões brasileiras. Thesaurus Editora de Brasília Ltda., Brasília. 